\title{
PENGGUNAAN MULTI MEDIA PEMBELAJARAN DAN KECERDASAN INTERPERSONAL SISWA TERHADAP HASIL BELAJAR TUNE UP MOTOR BENSIN
}

\author{
Bangun Sihotang dan R. Mursid \\ SMK Negeri 5 Medan dan PPs Universitas Negeri Medan \\ bangun.sht@gmail.com
}

\begin{abstract}
Abstrak: Penelitian ini bertujuan untuk mengetahui; hasil belajar Tune Up Motor Bensin siswa yang diajar dengan pembelajaran multimedia CD Interaktif dibandingkan dengan multimedia CD Program, hasil belajar Tune Up Motor Bensin siswa yang memiliki kecerdasan interpersonal tinggi dengan rendah, mengetahui interaksi antara pembelajaran multimedia dan kecerdasan interpersonal siswa terhadap hasil belajar Tune Up Motor Bensin. Metode penelitian menggunakan metode quasi eksperimen dengan desain penelitian faktorial $2 \times 2$, sedangkan teknik analisis data menggunakan ANAVA dua jalur pada taraf signifikansi $\alpha=0.05$. Hasil penelitian diperoleh: hasil belajar Tune Up Motor Bensin siswa yang diajarkan dengan pembelajaran CD Interaktif lebih baik dari pada yang diajarkan dengan pembelajaran multimedia CD Program, hasil belajar Tune Up Motor Bensin siswa yang memiliki kecerdasan interpersonal tinggi lebih baik dari pada yang memiliki kecerdasan interpersonal rendah, terdapat interaksi antarai pembelajaran multimedia dengan kecerdasan interpersonal dalam mempengaruhi hasil belajar siswa.
\end{abstract}

Kata Kunci: multimedia interaktif model tutorial, multimedia interaktif model linier, kecerdasan visual-spasial, kecerdasan kinestetik

\begin{abstract}
This study aims to determine; learning outcomes Tune Up Motor Gasoline students taught with multimedia learning Interactive $C D$ compared with the multimedia $C D$ program, learning outcomes Tune Up Motor Gasoline students with high interpersonal intelligence with low, the interaction between multimedia and interpersonal learning students' learning outcomes Tune Up Motorcycle gasoline. Method using quasi-experimental research design with a 2x2 factorial study, while data analysis techniques using ANOVA two lanes at the significance level $\square=0: 05$. The results were obtained: learning outcomes Tune Up Motor Gasoline taught students with learning Interactive $\mathrm{CD}$ better than those taught with multimedia learning $\mathrm{CD}$ program, learning outcomes Tune Up Motor Gasoline students with high interpersonal intelligence is better than the low interpersonal intelligence, there is an interaction be between multimedia learning with interpersonal intelligence in influencing student learning outcomes.
\end{abstract}

Keywords: model of interactive multimedia tutorials, interactive multimedia linear models, visualspatial intelligence, kinesthetic intelligence

\section{PENDAHULUAN}

Dalam pembelajaran Tune Up Motor

Bensin (TUMB) kebanyakan guru-guru menggunakan strategi pembelajaran ekspositori.

Strategi pembelajaran ekspositori adalah strategi pembelajaran yang menekankan kepada proses penyampaian materi secara verbal dari seorang guru kepada sekelompok siswa dengan maksud agar siswa dapat menguasai materi secara optimal. Pada dasarnya strategi pembelajaran ekspositori dilakukan dengan memberikan materi pembelajaran sacara langsung oleh guru.
Dengan melihat data yang ada pada SMK Negeri 5 Medan, bahwa hasil belajar mata pelajaran TUMB belum memuaskan. Hal ini terbukti dari hasil Ujian Akhir Semester 106 orang siswa yang terdiri dari 3 kelas dengan tingkat ketuntasan minimal pada nilai 7,00. Siswa yang mencapai tingkat ketuntasan dalam pembelajaran adalah 58 orang (54\%), sementara jumlah siswa yang tidak mencapai ketuntasan minimal adalah 48 orang (46\%). Menurut hasil diskusi dengan guru mata pelajaran TUMB nilai tersebut bukan nilai murni (sudah ditambah) dengan mempertimbangkan kehadiran, tugas, disiplin 
dan keaktifan dalam pembelajaran serta dari hasil pekerjaan praktikum TUMB laboratorium/bengkel.

Kimble (dalam Hergenhahn dan Olson, 2008:2) mendefinisikan belajar sebagai perubahan yang relatif permanen di dalam potensi behavioral (behavioral potentiality) yang terjadi sebagai akibat dari praktek yang diperkuat (reinforced practice). Pertama, belajar diukur berdasarkan perubahan dalam perilaku, dengan kata lain, hasil dari belajar harus selalu diterjemahkan ke dalam perilaku atau tindakan yang dapat diamati. Setelah menjalani proses belajar, pebelajar (learner) mampu melakukan sesuatu yang tidak bisa mereka lakukan sebelum mereka belajar. Kedua, perubahan behavioral ini relatif permanen; artinya, hanya sementara dan tidak menetap. Ketiga, perubahan perilaku ini tidak selalu terjadi secara langsung setelah proses belajar selesai. Kendati ada potensi untuk bertindak secara berbeda, potensi bertindak ini mungkin tidak akan diterjemahkan ke dalam bentuk perilaku secara langsung. Keempat, perubahan perilaku (potensi behavioral) berasal dari pengalaman atau praktek (latihan). Kelima, pengalaman atau praktek harus diperkuat artinya, hanya respon-respon yang menyebabkan penguatanlah yang akan dipelajari.

Mata pelajaran TUMB dimaksudkan untuk mempersiapkan peserta didik agar mampu mengantisipasi pesatnya perkembangan teknologi kenderaan ringan, melalui pembelajaran yang mengembangkan proses kemampuan berpikir (kognitif) dan psikomotorik untuk menghasilkan kompetensi pemeriksaan dan analisis, perawatan dan perbaikan motor bensin. Implementasi peraturan pemerintah No. 19 Tahun 2005 tentang Sistem Pendidikan Nasional membawa implikasi terhadap model pembelajaran serta teknik penilaian yang dilaksanakan di kelas. Ruang lingkup mata pelajaran TUMB sebagai berikut; (1) Teknik pemeriksaan dan analisis kerusakan motor bensin, (2) Teknik perawatan motor bensin, dan (3) Teknik perbaikan motor bensin.

Dengan demikian dapat disimpulkan bahwa pembelajaran TUMB adalah pembelajaran yang dapat membantu siswa untuk mengetahui teknik dalam merawat, memeriksa dan menaganlisis serta memperbaiki sistem dalam kenderaan motor bensin. Siswa juga dapat menggunakan segala potensi yang ada untuk dapat mengembangkan kemampuan diri. Penguasaan dalam TUMB diharapkan dapat memberikan motivasi dan kesenangan kepada siswa untuk belajar dan bekerja secara mandiri dengan cara yang lebih mudah.

Perkembangan komunikasi ini dapat memudahkan orang untuk mengerti pesan yang disampaikan dengan bantuan multimedia. Perry dalam Kadir dan Wahyuni (2005:302) mengatakan bahwa multimedia merupakan interaksi antara teks, suara, gambar statis, dan video. Ditinjau dari kata-kata pembentuknya, multimedia berarti "melibatkan berbagai media". Multi artinya banyak sedangkan media adalah sarana, alat atau perantara dalam hal ini bahasa, baik bahasa lisan, tulisan, gambar, suara/bunyi maupun gerak yang digunakan dalam proses penyampaian pesan (informasi, gagasan, himbauan dan sebagainya). Jadi, secara harfiah, istilah multimedia berarti banyak media atau sarana yang digunakan dalam penyampaian pesan. Dengan menggunakan multimedia, informasi dapat ditampilkan secara serentak melalui berbagai media. Pengguna dapat melihat informasi pada layar berupa tek maupun gambar serta suara dari sebuah speaker pada waktu yang bersamaan.

Parekh (2006:1) mengatakan informasi yang disampaikan dengan multimedia dapat berupa: (1) teks, berupa: buku, surat dan surat kabar), (2) gambar dan grafik, berupa: foto, grafik, peta, logo dan sketsa, (3) suara, berupa: radio, piringan hitam dan kaset audio dan (4) video dan animasi, berupa: tv, video kaset dan film. Lebih lanjut Parekh (2006:10) juga mengatakan bahwa multimedia juga diperuntukkan untuk tujuan kependidikan. Multimedia ini termasuk paket-paket pembelajaran dan simulasi dari percobaan laboratorium (terutama yang tidak dapat dilakukan dengan mudah). Aspek-aspek yang berbeda dari kurikulum yang tidak dapat dijelaskan atau ditangkap dengan mudah melalui teks dan gambar sederhana dapat disampaikan melalui video klip, animasi, pemodelan 3 dimensi, penjelasan audio dan lain-lain untuk membuat materi pelajaran lebih mudah dipahami. Keahlian instruktur terbaik yang digunakan untuk membuat dan mendistribusikan konten mereka kepada ribuan siswa di seluruh dunia sebagai bagian dari "pembelajaran jarak jauh" atau "e-learning" Program.

Multimedia non-linear interaktif adalah multimedia yang dilengkapi dengan alat pengontrol yang dapat dioperasikan oleh pengguna, sehingga pengguna dapat memilih 
apa yang dikehendakinya, seperti permainan komputer, multimedia pembelajaran dan sebagainya (Schwier dan Misanchuk : 1994). Dalam penggunaan komputer diperlukan kontrol dengan menggunakan keyboard, mouse dan alat input lainnya sehingga pengguna (user) dapat mengendalikan dan mengakses apa yang menjadi kebutuhan pengguna. Hal ini disebut interaktif dan multimedia yang dapat menangani interaktif pengguna disebut interaktif multimedia (multimedia interactive) atau disebut juga non-linier multimedia. Dalam banyak aplikasi pengguna dapat memilih apa yang dapat dikerjakan selanjutnya, bertanya dan mendapatkan jawaban apa yang mempengaruhi komputer untuk mengerjakan fungsi selanjutnya. Setiap pilihan interaktif dapat dibuat dengan menggunakan software multimedia.

Menurut Schwier dan Misanchuk (1994:6) mengatakan multimedia CD interaktif merupakan CD Program pembelajaran yang mencakup berbagai sumber yang terintegrasi dalam perintah-perintah dalam sebuah sistem berbasis computer. Multimedia ini sengaja dirancang dalam bagian-bagian berupa tanggapan tanggapan berupa menu, masalah, simulasi sebuah kejadian, pertanyaan dan lingkungan virtual yang terintegrasi dalam sebuah Program.

Menurut Gora (2005:1) multimedia CD Interaktif merupakan sebuah sistem multimedia yang dikembangkan dan dirancang untuk digunakan di rumah, sekolah dan kantor. Keuntungan penggunaan multimedia CD interaktif adalah pembelajaran bersifat mandiri dan interaktivitas yang tinggi, mampu meningkatkan tingkat ingatan dan biaya yang dibutuhkan tidak terlalu mahal. Multimedia CD Interaktif selalu memberikan lebih banyak pengalaman belajar, dengan teks, audio, video dan animasi yang semuanya itu digunakan untuk menyampaikan informasi. Secara khusus gambar akan ditampilkan bersamaan dengan title dan narasi suara untuk menyajikan konten utama. Klip video dapat digunakan untuk menampilkan tingkah laku manusia atau pekerjaan yang kompleks.

Menurut Schwier \& Misanchuk (1994:38) mengatakan multimedia CD Program merupakan rekaman panjang (Long Play) berupa film, informasi, materi pelajaran disimpan dalam bentuk optic yang berlapis plastic atau CD (compact disc). Secara umum film membutuhkan ruang penyimpanan yang sangat besar sehingga disimpan dalam sebuah media berbahan optic yang disebut CD Program. Selanjutnya Parekh (2006: 3) mengatakan multimedia CD Program pada dasarnya dibentuk dari kombinasi beberapa gambar dari sebuah kejadian yang ditampilkan secara berurutan pada kecepatan tertentu, sedangkan suara dimainkan bersama pada bagian latar. Dalam pembelajaran dengan menggunakan multimedia CD Program guru dapat menuntun siswa untuk menjalankan pengalaman mendengar, melihat dengan tenang, memusatkan perhatian terhadap materi yang disajikan. Pesan yang akan disampaikan dapat berupa fakta maupun fiktif, inovatif dan edukatif.

Menurut Sadiman (2003: 57) keunggulan dari penggunaan multimedia CD Program adalah: (1) dapat menarik perhatian untuk periode-periode yang singkat dari rangsangan luar yang lainnya; (2) dapat memperoleh informasi dari ahli-ahli spesialis; (3) menghemat waktu; (3) rekaman dapat diputar berulang-ulang; (5) dapat mengamati banyak objek yang bergerak (6) dapat mengatur tingkat kekerasan suara bila ada informasi yang akan disisipkan (7) gambar proyeksi dapat dihentikan untuk diamati secara seksama; (8) guru dapat menghentikan gerakan gambar yang diinginkan.

Kecerdasan/inteligensi merupakan kemampuan tertinggi dari jiwa mahluk hidup yang hanya dimiliki oleh manusia. Menurut Anastasi dkk, (1997) mengemukakan kecerdassan/inteligensi adalah kemampuan untuk mengetahui problem serta kondisi baru, kemampuan berpikir, kemampuan bekerja, kemampuan menguasai tingkah laku instriktif, serta kemampuan menerima hubungan yang kompleks. Sedangkan Wahab dkk, (2004) menjelaskan bahwa inteligensi adalah kemampuan yang dibawa sejak lahir yang memungkinkan seseorang berbuat sesuatu dengan cara tertentu. Atau kemampuan yang bersifat umum untuk mengadakan penyesuaian terhadap suatu situasi atau masalah kemampuan yang bersifat umum yang meliputi berbagai jenis psikis seperti abstrak, berpikir mekanis, matematis, memahami, mengingat bahasa dan sebagainya.

Howard Gardner

mendefinisikan multiple inteligensi sebagai kemempuan untuk memecahkan persoalan dan menghasilkan produk dalam suatu seting yang bermacam-macam dan dalam situasi yang nyata. Menurut Gardner ada beberapa kriteria mengenai multiple inteligensi yaitu; 
pengetahuan mengenai perkembangan individu yang nomal dan yang superior, (2) informasi mengenai kerusakan otak, 3) studi mengenai orang-orang eksepesional seperti individu yang luar biasa pintar, juga individu idiot savant, dan orang-orang autistic, (4) data psikometrik, dan (5) studi pelatihan psikologi. Gardner juga mengatakan bahwa inteligensi diindetifikasikannya bersifat universal sekalipun secara budaya tampak berbeda.

Menurut Gardner (1983) intelegensi interpersonal adalah kemampuan untuk mengerti dan menjadi peka terhadap perasaan, intense, motivasi, watak, tempramen orang lain. Secara umum intelegensi interpersonal ini berkaitan dengan kemampuan seseorang untuk menjalin relasi dan komunikasi dengan berbagai orang. Orang yang memiliki intelegensi interpersonal biasanya sangat mudah bekerja sama dengan orang lain, mudah berkomunikasi dengan orang lain . Hubungan dengan orang lain bagi mereka yang memiliki intelegensi inimenyenangkan dan sepertinya keluar begitu saja secara otomatis. Mereka dengan mudah mengenali dan membedakan perasaan serta apa yang dialami teman dan orang lain. Komunikasi verbal maupun dengan orang lain relative mudah.

Siswa yang mempunyai intelegensi interpersonal tinggi mudah bergaul dan berteman. Meskipun sebagai orang baru dalam suatu kelas atau sekolah, ia dengan cepat dapat masuk kedalam kelompok. Ia mudah berkomunikasi dan mengumpulkan teman lain. Bila dilepas seorang diri, ia akan dangan cepat mencari teman. Dalam konteks belajar, ia lebih suka belajar bersama dengan orang lain, lebih suka mengadakan studi kelompok, kecerdasan interpersonal ini merupakan kecerdasan yang lebih bersifat crystallized menurut konsep yang dikemukakan oleh Cattel dalam Azwar (1997).

Intelegensi crystallized dapat di pandang sebagai endapan pengalaman yang terjadi sewaktu inteligensi fluid bercampur dengan apa yang disebut intelegensi budaya. Intelegensi crystallized akan meningkat kadarnya dalam diri seorang seiring dengan bertambahnya pengetahuan, pengalaman dan ketermpilan-keterampilan yang dimiliki oleh individu. Inteligensi fluid cenderung tidak berubah setelah 14 tahun dan 15 tahun, sedangkan inteligensi crystallized masih dapat terus berkembang, sampai usia 34-40 tahun, bahkan lebih. Maka jelas bahwa kecerdasan interpersonal ini bersifat bisa berubah dan bisa ditingkatkan. Karena merupakan sebuah proses belajar dari pengalaman anak sehari-hari, bukan merupakan factor hereditas. Semua anak bisa memiliki kecerdasan interpersonal yang tinggi. Untuk itu anak membutuhkan bimbingan dan pengarahan dari orang tua untuk mampu mengembangkan kecerdasan interpersonalnya.

Tujuan penelitian ini adalah untuk mengetahui: (1) Perbedaan hasil belajar TUMB kelompok siswa yang diajarkan dengan menggunakan multimedia CD Interaktif dan kelompok siswa yang diajarkan dengan menggunakan multimedia CD Program; (2) Perbedaan hasil belajar TUMB antara kelompok siswa yang memiliki kecerdasan interpersonal tinggi dan kelompok siswa yang memiliki kecerdasan interpersonal rendah; dan (3) Interaksi antara pembelajaran menggunakan multimedia dengan kecerdasan interpersonal dalam memberikan mempengaruhi hasil belajar TUMB.

Berdasarkan kajian teori, penelitian yang relevan dan kerangka berfikir di atas maka hipotesis dalam penelitian ini adalah sebagai berikut :

1. Kelompok siswa yang dibelajarkan dengan menggunakan Multimedia CD interaktif memperoleh hasil belajar TUMB lebih tinggi dari kelompok siswa yang dibelajarkan dengan Multimedia CD Program.

2. Kelompok siswa yang memiliki kecerdasan/inteligensi interpersonal tinggi memperoleh hasil belajar TUMB lebih tinggi daripada kelompok siswa yang memiliki kecerdasan/inteligensi interpersonal rendah.

3. Terdapat interaksi antara pembelajaran dengan menggunakan multimedia dan kecerdasan/inteligensi interpersonal terhadap hasil belajar TUMB .

\section{METODE PENELITIAN}

Penelitian ini dilaksanakan di SMK Negeri 5 Jl. Timor No. 36 Medan. Penelitian ini dilaksanakan pada semester genap Tahun Ajaran 2011/2012. Populasi penelitian ini adalah semua siswa kelas XI, yang terdiri dari 3 kelas, masing masing kelas terdiri dari rata-rata 35 orang. Jadi keseluruhan populasi berjumlah 105 orang. Teknik pengambilan sampel penelitian ini adalah dengan menggunakan sampel kelompok secara acak (Cluster Random Sampling).

Metode yang dipergunakan dalam penelitian ini adalah quasi-eksperimen. Metode ini dipilih karena kelas yang dipakai untuk 
kelas perlakuan baik kelas pembelajaran dengan menggunakan multimedia CD Interaktif maupun kelas pembelajaran dengan menggunakan multimedia CD Program merupakan kelas yang sudah terbentuk sebelumnya dan karakteristik siswa adalah kecerdasan/inteligensi interpersonal.

Dalam menguji kebenaran hipotesis yang diajukan dalam penelitian ini dilakukan dengan menggunakan teknik analisis data analisis varians (ANAVA). Penggunaan teknik ini dimaksudkan agar hasil tes akhir yang dicapai oleh subjek penelitian benar-benar karena pengaruh dari perlakuan yang diberikan dalam proses penelitian dengan taraf signifikansi $\alpha=0,05$. Jika hasil pengujian menunjukkan terdapatnya interaksi maka perlu dilakukan uji lanjut. Dalam penggunaan ANAVA dua jalur harus memenuhi syarat sebagai berikut: (1) data yang digunakan harus berdistribusi normal, sehingga perlu dilakukan uji normalitas dengan menggunakan uji Lillifors, (2) data harus memiliki varians populasi homogen, sehingga dilakukan uji homogenitas varians dengan menggunakan uji Fisher dan uji Bartlet.

\section{HASIL DAN PEMBAHASAN \\ Hasil}

Tabel 1. Hasil Statistik Deskriptif

\begin{tabular}{|c|c|c|c|c|c|c|c|}
\hline \multirow{2}{*}{\multicolumn{2}{|c|}{ Variabel }} & \multicolumn{4}{|c|}{ Pembelajaran Multi Media } & \multirow{2}{*}{\multicolumn{2}{|c|}{ Total }} \\
\hline & & & CD I & & $\mathrm{CD} \mathrm{P}$ & & \\
\hline \multirow{12}{*}{ 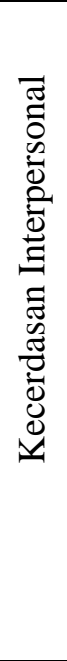 } & \multirow{6}{*}{$\begin{array}{l}\overrightarrow{D D} \\
\stackrel{0 D}{00} \\
\stackrel{D}{\Xi}\end{array}$} & $\mathrm{N}$ & 18 & $\mathrm{~N}$ & 18 & $\mathrm{~N}$ & 36 \\
\hline & & $\sum X$ & 1568 & $\sum X$ & 1454 & $\sum \mathrm{X}$ & 3022 \\
\hline & & $\bar{X}$ & 87.111 & $\bar{X}$ & 80.778 & $\bar{X}$ & 83.940 \\
\hline & & $\mathrm{s}^{2}$ & 24.458 & $\mathrm{~s}^{2}$ & 19.83 & $\mathrm{~s}^{2}$ & 34.83 \\
\hline & & $S$ & 4.945 & $S$ & 4.453 & $S$ & 5.641 \\
\hline & & $\overline{\bar{X}}$ & 137006 & $\overline{\bar{X}}$ & 117788 & $\overline{\bar{X}}$ & 254794 \\
\hline & \multirow{6}{*}{ 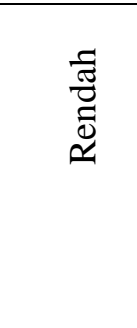 } & $\mathrm{N}$ & 18 & $\mathrm{~N}$ & 16 & $\mathrm{~N}$ & 34 \\
\hline & & $\sum \mathrm{X}$ & 1364 & $\sum \mathrm{X}$ & 1218 & $\sum X$ & 2582 \\
\hline & & $\bar{X}$ & 75.778 & $\overline{\bar{X}}$ & 76.125 & $\overline{\bar{X}}$ & 75.94 \\
\hline & & $\mathrm{s}^{2}$ & 20.536 & $s^{2}$ & 31.45 & $\mathrm{~s}^{2}$ & 24.91 \\
\hline & & $S$ & 4.532 & $\mathrm{~s}$ & 5.608 & $S$ & 4.999 \\
\hline & & $\bar{X}$ & 103710 & $\bar{X}$ & 93192 & $\bar{X}$ & 196902 \\
\hline \multirow{6}{*}{\multicolumn{2}{|c|}{ Total }} & $\mathrm{N}$ & 36 & $\mathrm{n}$ & 34 & $\mathrm{n}_{\mathrm{t}}$ & 70 \\
\hline & & $\sum X$ & 2932 & $\sum X$ & 2672 & $\sum X_{t}$ & 5604 \\
\hline & & $\bar{X}$ & 81.444 & $\bar{X}$ & 78.588 & $\bar{X}$ & 80.06 \\
\hline & & $\mathrm{s}^{2}$ & 54.88 & $\mathrm{~s}^{2}$ & 30.068 & $\mathrm{~s}^{2}$ & 44.29 \\
\hline & & $S$ & 7.408 & $\mathrm{~s}$ & 5.483 & $S$ & 6.655 \\
\hline & & $\overline{\bar{X}}$ & 240716 & $\overline{\bar{X}}$ & 210980 & $\overline{\bar{X}}$ & 451696 \\
\hline
\end{tabular}

\section{Pengujian Hipotesis} bawah ini.

Secara keseluruhan hasil Anava untuk pengujian hipotesis dapat dilihat pada Tabel 2. di Tabel 2. Rangkuman Hasil Anava Secara Keseluruhan Data Hasil Belajar TUMB

\begin{tabular}{|c|c|c|c|c|c|}
\hline \multirow{2}{*}{ Sumber variasi } & \multirow{2}{*}{$\mathrm{dk}$} & \multirow{2}{*}{$\mathrm{JK}$} & \multirow{2}{*}{ RJK } & \multirow{2}{*}{$F_{\text {hitung }}$} & $F_{\text {tabel(1.66) }}$ \\
\hline & & & & & $(\alpha=0.05)$ \\
\hline Pembelajaran Multi Media & 1 & 142.647 & 142.647 & 5.982 & \multirow{3}{*}{3.99} \\
\hline Kecerdasan Interoersonal & 1 & 1120.000 & 1120.000 & 46.971 & \\
\hline Interaksi & 1 & 219.374 & 219.374 & 9.200 & \\
\hline
\end{tabular}




\begin{tabular}{|l|l|l|l|l|l|} 
Galat & 66 & 1573.750 & 23.845 & & \\
\hline Total & 69 & 3055.771 & & & \\
\hline
\end{tabular}

1. Perbedaan Hasil belajar TUMB Antara Siswa Yang Memperoleh Multimedia CD Interaktif dan CD Program. adalah :

Adapun hipotesis statistik yang diuji

Ho : $\mu \mathrm{A}_{1} \leq \mu \mathrm{A}_{2}$

$\mathrm{Ha}: \mu \mathrm{A}_{1}>\mu \mathrm{A}_{2}$

Berdasarkan hasil pengujian hipotesis pada tabel 4.13 di atas, maka diperoleh hasil perhitungan data Multimedia, dimana $\mathrm{F}_{\text {hitung }}=$ 5.982, sementara nilai kritik $F_{\text {tabel }}$ dengan $\mathrm{dk}=$ $(1,66)$ dan $\alpha=0,05$ adalah sebesar 3,99. Hasil ini menunjukkan bahwa $\mathrm{F}_{\text {hitung }}=5,982>\mathrm{F}_{\text {tabel }}=$ 3,99 sehingga Hipotesis Nol (Ho) ditolak, dengan demikian hipotesis penelitian yang menyatakan bahwa hasil belajar TUMB siswa yang dibelajarkan dengan Multimedia CD Interaktif lebih tinggi dari pada siswa yang diajarkan dengan Multimedia CD Program teruji kebenarannya.

\section{Perbedaan Hasil belajar TUMB Antara Siswa Yang Memiliki Kecerdasan Interpersonal Tinggi Dan Rendah.} adalah :

Adapun hipotesis statistik yang diuji

Ho : $\mu \mathrm{B}_{1} \leq \mu \mathrm{B}_{2}$

$\mathrm{Ha}: \mu \mathrm{B}_{1}>\mu \mathrm{B}_{2}$

Berdasarkan hasil pengujian hipotesis pada Tabel 4.13. di atas diperoleh hasil perhitungan data Kecerdasan Interpersonal, dimana $F_{\text {hitung }}=46,971$ dan nilai kritik $F_{\text {tabel }}$ dengan $\mathrm{dk}=(1,66)$ dan $\alpha=0.05$ adalah 3,99. Hasil ini menunjukkan bahwa $F_{\text {hitung }}=46,971>$ $F_{\text {tabel. }}=3,99$ sehingga Hipotesis $\mathrm{Nol}$ (Ho) ditolak, dengan demikian hipotesis penelitian yang menyatakan bahwa siswa yang memiliki
Kecerdasan Interpersonal tinggi memperoleh hasil belajar TUMB yang lebih tinggi dari pada siswa yang memiliki Kecerdasan Interpersonal rendah teruji kebenarannya.

\section{Interaksi Antara Multimedia dan Kecerdasan Interpersonal Siswa Dalam Mempengaruhi Hasil belajar TUMB} adalah :

Adapun hipotesis statistik yang diuji

$$
\begin{aligned}
& \text { Ho: }: \text { A } \times \text { B } \leq 0 \\
& \text { Ha : A } \times \text { B } \neq 0
\end{aligned}
$$

Berdasarkan hasil pengujian hipotesis di atas diperoleh perhitungan interaksi Multimedia dengan Kecerdasan Interpersonal, dimana $F_{\text {hitung }}=9,200$ dan nilai kritik $F_{\text {tabel }}$ dengan $\mathrm{dk}=(1,66)$ dan $\alpha=0,05$ adalah 3,99. Hasil ini menunjukkan bahwa $F_{\text {hitung }}=9,200>$ $\mathrm{F}_{\text {tabel. }}=3,99$ sehingga Hipotesis $\mathrm{Nol}(\mathrm{Ho})$ ditolak, dengan demikian hipotesis penelitian yang menyatakan bahwa terdapat interaksi antara Multimedia dan Kecerdasan Interpersonal dalam memberikan pengaruh terhadap hasil belajar TUMB teruji kebenarannya.

Karena ada interaksi antara Multimedia dan Kecerdasan Interpersonal dalam mempengaruhi hasil belajar TUMB, maka perlu dilakukan uji lanjutan (post hoc test), untuk mengetahui rata-rata hasil belajar sampel mana yang berbeda. Untuk melihat bentuk interaksi antara Multimedia dan Kecerdasan Interpersonal dalam mempengaruhi hasil belajar TUMB, dilakukan uji lanjut dengan menggunakan uji Scheffe. Ringkasan hasil uji Scheffe dapat dilihat pada Tabel 3. berikut:

Tabel 3. Ringkasan Hasil Perhitungan Uji Scheffe

\begin{tabular}{|c|c|c|c|}
\hline $\begin{array}{l}\text { Nilai rata-rata kelompok } \\
\text { yang dibandingkan }\end{array}$ & \multirow{2}{*}{$\mathrm{F}_{\text {hitung }}$} & $\mathrm{F}_{\text {tabel(3.66) }}$ & \multirow{2}{*}{ Keterangan } \\
\cline { 1 - 1 }$\mu \mathrm{A} 1 \mathrm{~B} 1$ dengan $\mu \mathrm{A} 2 \mathrm{~B} 1$ & 3,891 & 2,73 & Signifikan \\
\hline$\mu \mathrm{A} 1 \mathrm{~B} 1$ dengan $\mu \mathrm{A} 2 \mathrm{~B} 2$ & 6,548 & 2,73 & Signifikan \\
\hline$\mu \mathrm{A} 1 \mathrm{~B} 1$ dengan $\mu \mathrm{A} 1 \mathrm{~B} 2$ & 6,963 & 2,73 & Signifikan \\
\hline$\mu \mathrm{A} 2 \mathrm{~B} 1$ dengan $\mu \mathrm{A} 2 \mathrm{~B} 2$ & 2,859 & 2,73 & Signifikan \\
\hline$\mu \mathrm{A} 2 \mathrm{~B} 1$ dengan $\mu \mathrm{A} 1 \mathrm{~B} 2$ & 3,072 & 2,73 & Signifikan \\
\hline$\mu \mathrm{A} 1 \mathrm{~B} 2$ dengan $\mu \mathrm{A} 2 \mathrm{~B} 2$ & 0,207 & 2,73 & Tidak Signifikan \\
\hline
\end{tabular}


Kriteria penerimaan jika: $F_{\text {hitung }}>F_{\text {tabel, }}$ maka teruji secara signifikan. Berdasarkan hasil uji Scheffe pada Tabel 4.14. di atas dapat dilihat bahwa terdapat 6 (enam) pasang hipotesis statistik, yakni:

a. Dari hasil perhitungan dengan menggunakan uji Scheffe pada tabel di atas menunjukkan bahwa $\mathrm{F}_{\text {hitung }}=3891>\mathrm{F}_{\text {tabel }}=2,73$, sehingga memberikan keputusan menolak Ho. Dengan demikian, hipotesis penelitian yang menyatakan bahwa hasil belajar TUMB siswa jika diajar menggunakan Multimedia CD Interaktif lebih tinggi dibandingkan dengan Multimedia CD Program untuk siswa yang memiliki Kecerdasan Interpersonal tinggi teruji kebenarannya.

b. Dari hasil perhitungan dengan menggunakan uji Scheffe pada tabel di atas menunjukkan $\mathrm{F}_{\text {hitung }}=6,548>\mathrm{F}_{\text {tabel }}=2,73$, sehingga memberikan keputusan menolak Ho. Dengan demikian, hipotesis penelitian yang menyatakan bahwa hasil belajar TUMB siswa yang memiliki Kecerdasan Interpersonal tinggi jika diajar dengan Multimedia CD Interaktif lebih tinggi daripada hasil belajar siswa yang memiliki Kecerdasan Interpersonal rendah jika diajar dengan Multimedia CD Program teruji kebenarannya. Dengan demikian hasil belajar TUMB siswa yang diajar menggunakan Multimedia CD Interaktif terdapat perbedaan dibandingkan dengan hasil belajar TUMB siswa yang diajar menggunakan Multimedia CD Program untuk siswa yang memiliki Kecerdasan Interpersonal rendah.

c. Dari hasil perhitungan dengan menggunakan uji Scheffe pada Tabel di atas menunjukkan $\mathrm{F}_{\text {hitung }}=6,963>\mathrm{F}_{\text {tabel }}=273$, sehingga memberikan keputusan menolak Ho. Dengan demikian, hipotesis penelitian yang menyatakan bahwa Hasil belajar TUMB siswa dengan Kecerdasan Interpersonal tinggi jika diajar menggunakan Multimedia $\mathrm{CD}$ Interaktif lebih tinggi dibandingkan dengan siswa yang memiliki Kecerdasan Interpersonal rendah teruji kebenarannya.

d. Dari hasil perhitungan dengan menggunakan uji Scheffe pada Tabel di atas menunjukkan $\mathrm{F}_{\text {hitung }}=2,859>\mathrm{F}_{\text {tabel }}=2,73$, sehingga memberikan keputusan menolak Ho. Dengan demikian, hipotesis penelitian yang menyatakan bahwa hasil belajar TUMB siswa yang memiliki Kecerdasan Interpersonal tinggi jika diajarkan dengan Multimedia CD Program lebih tinggi dari pada hasil belajar TUMB siswa yang memiliki Kecerdasan Interpersonal rendah jika diajarkan dengan Multimedia CD Program teruji kebenarannya. Dengan demikian terdapat perbedaan antara hasil belajar TUMB siswa yang diajar dengan Multimedia CD Program baik yang memiliki Kecerdasan Interpersonal tinggi maupun yang memiliki Kecerdasan Interpersonal rendah.

e. Dari hasil perhitungan dengan menggunakan uji Scheffe pada Tabel di atas menunjukkan $\mathrm{F}_{\text {hitung }}=3,072>\mathrm{F}_{\text {tabel }}=2,73$, sehingga memberikan keputusan menolak Ho. Dengan demikian, hipotesis penelitian yang menyatakan bahwa Hasil belajar TUMB siswa dengan Kecerdasan Interpersonal tinggi yang diajar menggunakan Multimedia CD Program lebih tinggi dibandingkan dengan siswa yang memiliki Kecerdasan Interpersonal rendah yang diajar dengan menggunakan Multimedia CD Program teruji kebenarannya.

f. Dari hasil perhitungan dengan menggunakan uji Scheffe pada Tabel di atas menunjukkan $\mathrm{F}_{\text {hitung }}=0,207<\mathrm{F}_{\text {tabel }}=273$, sehingga memberikan keputusan menerima Ho. Dengan demikian hipotesis penelitian yang menyatakan bahwa hasil belajar TUMB siswa yang memiliki Kecerdasan Interpersonal rendah jika menggunakan Multimedia CD Interaktif lebih tinggi dibandingkan menggunakan Multimedia CD Program untuk Kecerdasan Interpersonal rendah tidak teruji kebenarannya. Dengan demikian tidak terdapat perbedaan antara hasil belajar siswa yang diajar dengan Multimedia CD Program dan memiliki Kecerdasan Interpersonal rendah dengan hasil belajar siswa yang diajar dengan Multimedia CD Interaktif dan memiliki Kecerdasan Interpersonal rendah.

Selanjutnya adanya interaksi antara variabel Multimedia dan Kecerdasan Interpersonal terhadap hasil belajar TUMB siswa, maka perlu diberikan gambaran grafik estimasi yang menunjukkan adanya interaksi tersebut. 


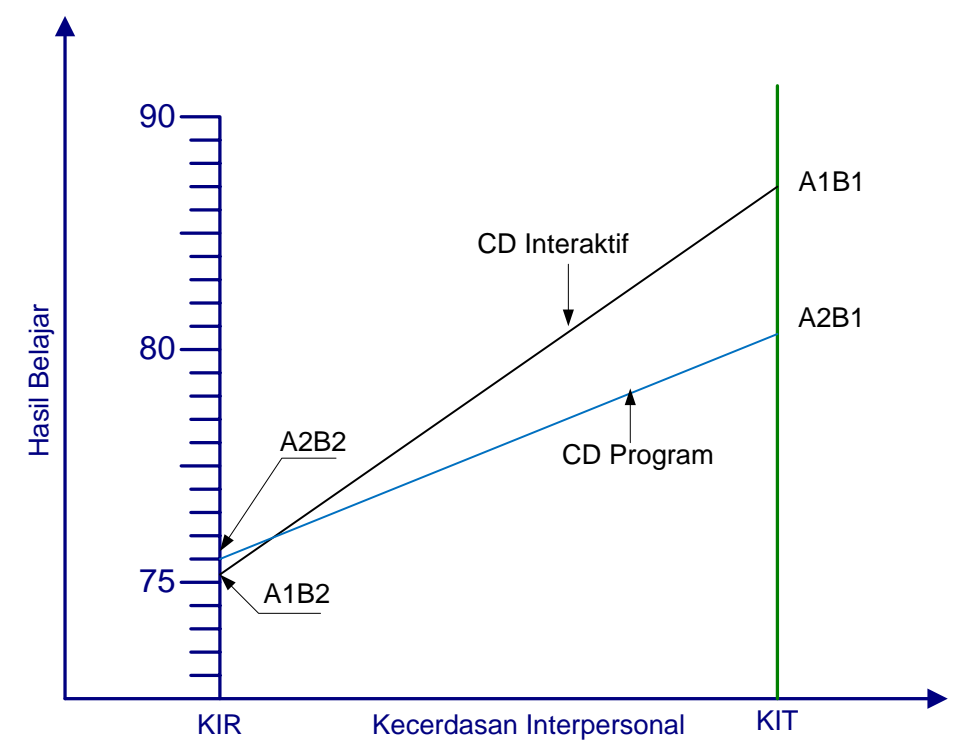

Gambar 1. Model Interaksi Antara Multimedia dan Kecerdasan Interpersonal Terhadap Hasil belajar TUMB Siswa

\section{Pembahasan}

Perbedaan Hasil Belajar TUMB antara siswa yang dibelajarkan dengan menggunakan multimedia cd interaktif dan siswa yang dibelajarkan dengan menggunakan multimedia CD program. Dari hasil pengolahan data yang dilakukan terdapat perbedaan hasil belajar TUMB antara siswa yang dibelajarkan dengan multimedia CD interaktif dan siswa yang dibelajarkan dengan multimedia CD Program yaitu rata-rata hasil belajar TUMB siswa yang belajarkan dengan menggunakan multimedia CD interaktif lebih tinggi dibandingkan dengan siswa yang debelajarkan dengan menggunakan multimedia CD Program.

Pengguanaan multimedia CD interaktif dalam pembelajaran TUMB memungkinkan siswa untuk berinteraksi langsung dan melakukan kontrol langsung pada sumber informasi sehingga memungkinkan siswa untuk langsung menemukan informasi-informasi yang sedang dipelajari. Pembelajaran dengan multimedia CD interaktif memungkinkan guru bebas melakukan interaksi dengan siswa sehingga pembelajaran bersifat interaktif yang membuat pembelajaran terfokus pada informasi yang sedang dipelajari. Pada pembelajaran ini guru mengacu pada penyajian informasi akademik yang baru yang penyampaiannya dapat dihentikan pada setiap urutan-urutan (sekuensi) yang dikehendaki sehingga siswa tidak mengalami banyak kesulitan untuk mengikuti proses pembelajaran dan siswa dapat mengulang sejenak suatu informasi yang kurang dipahami. Pembelajaran dengan menggunakan multimedia CD interaktif lebih mengutamakan variasi teknik penyajian yang menarik yaitu dengan menggabungkan penggunaan media audio, visual dan animasi sehingga penyampaian informasi menarik dan memberikan kesempatan kepada siswa untuk aktif dan kreatif yang dapat berpengaruh positif dalam mengingkatkan hasil belajar TUMB siswa.

Sementara pada proses dengan menggunakan multimedia CD Program siswa tidak berinteraksi atau melakukan kontrol langsung langsung pada sumber informasi dan pembelajaran didominasi oleh guru dengan menyajikan informasi secara linier. Pada proses penyajiannya tidak dapat dihenTUMBan pada setiap urutan-urutan (sekuensi) yang dikehendaki siswa namun tampilan dari informasi yang disampaikan realistis karena didominasi oleh informasi rekaman video. Secara rinmgkas dapat dinyatakan bahwa teknik penyajian informasi kurang bervariasi dibandingkan dengan penggunaan multimedia $\mathrm{CD}$ interaktif. Pembelajaran dengan menggunakan multimedia $\mathrm{CD}$ Program menempatkan guru menggunakan kontrol pembelajaran dengan aktif, sementara siswa relatif pasif menerima dan mengikuti apa yang disampaikan guru. Guru menyampaikan materi secara terstruktur dengan harapan materi pelajaran yang disampaikan dapat dikuasai dengan baik dengan terfokus kepada kemampuan akademik.

Meskipun dalam penelitian diperoleh data bahwa hasil belajar TUMB siswa lebih 
tinggi jika dibelajarkan dengan multimedia CD interaktif daripada hasil belajar TUMB siswa yang dibelajarkan dengan multimedia $\mathrm{CD}$ Program, namun dalam pelaksanaannya kedua multimedia pembelajaran ini secara umum telah mampu meningkatkan pemahaman dan hasil belajar TUMB siswa. Dengan demikian dapat disimpulkan bahwa hasil belajar TUMB siswa yang dibelajarkan dengan menggunakan multimedia $C D$ interaktif lebih tinggi dibandingkan dengan hasil belajar TUMB siswa yang dibelajarkan dengan menggunakan multimedia CD Program.

Temuan penelitian ini juga mendudukung penelitian yang dilaksanakan oleh Junita (2009) yang menyimpulkan bahwa penggunaan multimedia sangat mendorong peningkatan hasil belajar siswa dan dapat meningkatkan kemampuan siswa dalam belajar mandiri pada mata pelajaran TUMB.

Perbedaan Hasil Belajar TUMB Antara Siswa Yang Memiliki Kecerdasan Interpersonal Tinggi Dan Siswa Yang Memiliki Kecerdasan Interpersonal Rendah. Hasil penelitian menunjukkan bahwa rata-rata hasil belajar TUMB siswa yang memiliki kecerdasan Interpersonal tinggi lebih tinggi daripada hasil belajar TUMB siswa yang memiliki kecerdasan Interpersonal rendah. Hal ini mengindikasikan bahwa siswa yang memiliki kecerdasan Interpersonal tinggi lebih mampu memahami pelajaran TUMB dibandingkan dengan siswa yang memiliki kecerdasan Interpersonal rendah. Siswa yang memiliki kecerdasan Interpersonal tinggi biasanya memiliki karakteristik berupa: (1) kemampuan memotivasi diri, (2) ketahanan dalam menghadapi frustasi, (3) kemampuan mengendalikan dorongan hati dan tidak melebih-lebihkan kesenangan, dan (4) kemampuan menjaga suasana hati dan menjaga agar beban stres tidak melumpuhkan kemampuan berfikir, berempati dan berdoa. Sedangkan siswa yang memiliki kecerdasan emosinal rendah memiliki karakteristik: (1) menarik diri dari pergaulan atau masalah, (2) cemas dan depresi, menyendiri, sering takut dan cemas, merasa gugup dan sedih. (3) memiliki masalah dalam pola pikir, kurang mampu memusatkan perhatian, melamun. (4) agresif: bergaul dengan anak-anak yang bermasalah, bohong dan menipu, sering bertengkar, bersikap kasar terhadap orang lain, menuntut perhatian, merusak milik orang lain, keras kepala dan suasana hati sering berubah-ubah.
Berdasarkan karakteristik kecerdasan Interpersonal diatas, siswa yang memiliki kecerdasan Interpersonal tinggi akan memperoleh hasil belajar yang lebih tinggi daripada siswa yang memiliki kecerdasan Interpersonal rendah, khususnya dalam pembelajaran TUMB karena dalam pembelajaran TUMB dibutuhkan kesabaran, keuletan, kreatifitas, motivasi dan kegigihan dalam mengetahui teknologi yang baru beserta aplikasinya yang sangat berhubungan dalam kehidupan sehari hari.

Apabila seseorang memiliki kecerdasan Interpersonal rendah maka cenderung menarik diri dari pergaulan, tertutup, merasa tidak memiliki kemampuan dalam menguasai materi pembelajaran dan kurang percaya diri bahwa mereka dapat memperoleh hasil yang baik, jika hal ini terjadi maka selanjutnya siswa tersebut akan mengalami kesulitan dalam memahami dan menerapkan dalam kehidupan sehari-hari. Kesimpulan penelitian ini mendukung terori yang dikemukakan oleh Goleman (2007) bahwa kecerdasan Interpersonal merupakan aktifitas pengendalian diri, semangat dan ketekunan serta kemampuan memotivasi diri, hal tersebut merupakan karakterisTUMB siswa yang memiliki kecerdasan Interpersonal tinggi.

Hasil Penelitian ini mendukung penelitian sebelumnya yang dilakukan oleh karo-karo (2004) tentang pengaruh antara media dan kecerdasan Interpersonal terhadap hasil belajar IPA mahasiswa PGSD FIP Unimed Medan yang menyimpulkan bahwa kecerdasan Interpersonal tinggi memberikan pengaruh yang lebih besar terhadap hasil belajar IPA jika dibandingkan dengan kelompok mahasiswa yang memiliki kecerdasan Interpersonal rendah. Interaksi Antara Multimedia Pembelajaran dan Kecerdasan Interpersonal Terhadap Hasil Belajar TUMB. Temuan penelitian menunjukkan bahwa terdapat interaksi antara multimedia pembelajaran dan kecerdasan Interpersonal terhadap hasil belajar TUMB. Siswa yang memiliki kecerdasan Interpersonal tinggi yang dibelajarkan dengan multimedia $\mathrm{CD}$ interaktif memperoleh hasil belajar TUMB yang lebih tinggi daripada siswa yang memiliki kecerdasan Interpersonal tinggi yang dibelajarkan dengan menggunakan multimedia CD Program. Demikian pula siswa yang memiliki kecerdasan Interpersonal rendah yang dibelajarkan dengan menggunakan multimedia CD interaktif memperoleh hasil belajar TUMB yang lebih rendah dibandingkan dengan siswa yang dibelajarkan dengan 
menggunakan multimedia CD Program. Walaupun dalam penelitian ini tidak terdapad perbedaan yang signifikan. Hal ini mengindikasikan adanya interaksi antara penggunaan multimedia pembelajaran dengan kecerdasan Interpersonal terhadap hasil belajar TUMB siswa.

Multimedia interaktif merupakan multimedia pembelajaran yang menuntut ada nya interaksi langsung dengan sumber informasi sehingga dapat meningkatkan rasa keingin tahuan, minat, kreatifitas, motivasi belajar bagi siswa yang memilki kecerdasan Interpersonal tinggi. Sejalan dengan itu bagi siswa yang memiliki kecerdasan Interpersonal tinggi akan terpacu untuk lebih giat belajar dan mampu mengendalian diri karena mereka selalu optimis untuk dapat mengetahui informasi tentang tujuan penerapan TUMB dalam kehidupan sehari hari dan meningkatkan hasil belajarnya. Sedangkan siswa yang memilki kecerdasan Interpersonal rendah mungkin akan merasa khawatir dan was-was kalau mereka tidak mampu mengikuti pembelajaran. Hal ini terjadi karena karakterisrtik kecerdasan Interpersonal rendah adalah kurangnya motivasi belajar, kurangnya percaya diri akibat tidak tidak mampu mengubah keadaan yang buruk. Siswa yang memilki kecerdasan Interpersonal rendah juga kurang mampu mengendalikan diri dan menangkap sinyal-sinyal sosial yang mengisiaratkan apa yang dikehendaki oleh orang lain sehingga dalam komunikasi dengan guru dalam pembelajaran tidak terjadi dengan baik yang berakibat dapat melunturkan semangat belajar siswa jika dibelajarkan dengan menggunakan multimedia CD interaktif.

Multimedia CD Program merupakan pembelajaran yang berorientasi pada guru dengan materi yang disajikan dikemas dalam bentuk video yang bersifat linier sehingga lebih cocok bagi siswa yang memiliki kecerdasan Interpersonal rendah, hal ini disebabkan siswa yang memilki kecerdasan Interpersonal cenderung pasif menunggu bimbingan dari guru. Dengan demikian guru memiliki banyak kesempatan untuk memberikan motivasi, semangat dan arahan sehingga siswa lebih termotivasi dan terdorong dalam mengetahui dan memahami TUMB dalam kehidupan sehari-hari dan meningkatkan hasil belajarnya. Akan tetapi jika pembelajaran multimedia CD Program diberikan kepada siswa yang memilki kecerdasan tinggi akan menimbulkan kebosanan dan kejenuhan. Hal ini disebabkan proses pembelajaran terkesan monoton dan kurang memiliki variasi dalam penyajiannya serta pembelajaran kurang memberikan kesempatan kepada siswa untuk aktif dan kreatif. Dengan dimikian hasil belajar TUMB siswa yang memiliki kecerdasaran Interpersonal rendah lebih tinggi dibandingkan dengan siswa yang memiliki kecerdasan Interpersonal tinggi jika dibelajarkan dengan menggunakan multimedia CD Program. Dengan demikian pembelajaran multimedia $\mathrm{CD}$ interaktif lebih tepat dibelajarakan kepada siswa yang memiliki kecerdasan Interpersonal tinggi dan pemberlajaran dengan menggunakan multimedia CD Program lebih tepat diberikan kepada siswa yang memiliki kecerdasan Interpersonal rendah.

\section{PENUTUP \\ Simpulan}

Simpulan hasil penelitian ini adalah sebagai berikut:

1. Hasil belajar TUMB siswa dengan multimedia pembelajaran $\mathrm{CD}$ Interaktif lebih baik dibandingkan dengan multimedia pembelajaran CD Program. Dalam hal ini siswa yang dibelajarkan dengan menggunakan multimedia pembelajaran $\mathrm{CD}$ Interaktif lebih baik dibandingkan dengan hasil belajar siswa yang dibelajarkan dengan multimedia pembelajaran CD Program.

2. Hasil belajar siswa yang memiliki kecerdasan interpersonal tinggi lebih baik dibandingkan dengan hasil belajar siswa yang memiliki kecerdasan interpersonal rendah. Dengan demikian siswa yang memiliki kecerdasan interpersonal tinggi memperoleh hasil belajar TUMB yang lebih baik dibandingkan dengan siswa yang memiliki kecerdasan interpersonal rendah.

3. Terdapat interaksi antara multimedia pembelajaran dan kecerdasan interpersonal dalam mempengaruhi hasil belajar TUMB.

a. Hasil belajar TUMB siswa yang memiliki memilik kecerdasan interpersonal tinggi yang diajar menggunakan multimedia pembelajaran $C D$ Interaktif lebih tinggi dibandingkan dengan hasil belajar TUMB siswa yang memiliki kecerdasan interpersonal tinggi yang diajar dengan multimedia pembelajaran CD Program.

b. Hasil belajar TUMB siswa yang memiliki memilik kecerdasan interpersonal tinggi yang diajar menggunakan multimedia pembelajaran $\mathrm{CD}$ Interaktif lebih tinggi dibandingkan dengan hasil belajar TUMB siswa yang memiliki kecerdasan 
interpersonal rendah yang diajar dengan multimedia pembelajaran CD Program

c. Hasil belajar TUMB siswa yang memiliki memilik kecerdasan interpersonal tinggi yang diajar menggunakan multimedia pembelajaran $\mathrm{CD}$ Interaktif lebih tinggi dibandingkan dengan hasil belajar TUMB siswa yang memiliki kecerdasan interpersonal rendah yang diajar dengan multimedia pembelajaran CD Interaktif.

d. Hasil belajar TUMB siswa yang memiliki memilik kecerdasan interpersonal tinggi yang diajar menggunakan multimedia pembelajaran CD Program lebih tinggi dibandingkan dengan hasil belajar TUMB siswa yang memiliki kecerdasan interpersonal rendah yang diajar dengan multimedia pembelajaran CD Program

e. Hasil belajar TUMB siswa yang memiliki memilik kecerdasan interpersonal tinggi yang diajar menggunakan multimedia pembelajaran CD Program lebih tinggi dibandingkan dengan hasil belajar TUMB siswa yang memiliki kecerdasan interpersonal rendah yang diajar dengan multimedia pembelajaran CD Interaktif

f. Hasil belajar TUMB siswa yang memiliki memilik kecerdasan interpersonal rendah yang diajar menggunakan multimedia pembelajaran CD Interaktif lebih rendah dibandingkan dengan hasil belajar TUMB siswa yang memiliki kecerdasan interpersonal rendah yang diajar dengan multimedia pembelajaran CD Program

\section{Saran}

Berdasarkan hasil penelitian, simpulan, dan keterbatasan penelitian, maka dikemukakan saran-saran sebagai berikut:.

1. Oleh karena hasil belajar siswa yang diajar Multimedia pembelajaran CD Interaktif lebih tinggi dari hasil belajar siswa yang diajar dengan multimedia pembelajaran $\mathrm{CD}$ Program, maka disarankan kedepan guru TUMB untuk menggunakan multimedia pembelajaran $\mathrm{CD}$ Interaktif dalam pembelajaran Mata pelajaran TUMB.

2. Guru Mata pelajaran TUMB kedepan perlu memperhatikan kecerdasan interpersonal siswa yang merupakan aspek kognitif memberikan pengaruh yang besar terhadap hasil belajar siswa.

3. Oleh multimedia pembelajaran CD Interaktif memberikan hasil belajar yang lebih tinggi untuk siswa yang memiliki kecerdasan interpersonal tinggi dalam meningkatkan hasil belajar TUMB, maka disarankan khususnya pada para guru Mata Pelajaran TUMB untuk menggunakan multimedia pembelajaran $\mathrm{CD}$ Interaktif dalam membelajarkan TUMB untuk siswa yang memiliki kecerdasan interpersonal tinggi.

4. Untuk siswa yang memiliki kecerdasan interpersonal rendah multimedia pembelajaran CD Program memberikan hasil belajar mata pelajaran TUMB yang lebih tinggi, maka disarankan guru Pelajaran TUMB untuk menerapkan multimedia pembelajaran CD Program dalam membelajarkan siswa yang memiliki kecerdasan interpersonal rendah.

5. Karakteristik siswa yang dijadikan variabel moderator dalam penelitian ini adalah hanya kecerdasan interpersonal. Disarankan untuk penelitian lanjut, melibatkan karakteristik siswa yang lain guna melengkapi kajian penelitian ini, seperti kecerdasan interpersonal, bakat, tingkat kreativitas, dan lain sebagainya.

\section{DAFTAR PUSTAKA}

Anastasi , A. Susana, U., (1997), Test Psikologi (Psychological Testing, 7e) Edisi Bahasa Indonesia Jilid I, New York: Macmillan Publising Co,INC.

Anderson, M. (1999), The Depelopment of Intelligence, UK: Psychological Press

Arikunto, S., (2002), Dasar-Dasar Evaluasi Pendidikan Edisi Revisi, Jakarta:Bumi Aksara

Arikunto, S. (1993)., Manajemen Pengajaran Secara Manusia, Jakarta: Bumi Aksara.

Arikunto, S. (1999), Prosedur Penelitian Suatu Pendekatan Praktek, Jakarta: Rineka Cipta.

Atkinson, R. Richart, A. E., (1999), Pengantar Psikologi Jilid 2 (Terjemahan NurjanahAgus), Jakarta: Erlangga.

Azwar, S. (1997), Pengantar Psikologi Inteligensi, Yokjakarta: Pustaka Pelajar.

Bloom, B. S., (2009), Taxonomi of Educational Objective: Hand Book I: Cognitive Domain New York.

Chauchman, S.S., (2001), Advanced Educational Psycholoy Sixth Revised Edition, New Dlhi: Vikas Publising House PVT LTD.

Djiwandono, S. E. W., (2006), Psikologi Pendidikan, Jakarta: Gramedia.

Gagne, R. M., and Briggs, L. J., (1979), Principles of Intruction, $\left(2^{\text {nd }} E d\right)$, London: Scott, Foresman. 
Gardner , H. (1983), Multiple Intelligences (Kecerdasan Majemuk), Batam: Interaksara.

Garas, W. (2005), Membuat CD Multimedia Interaktif Untuk Bahan Ajar Elerning, Jakarta: Elexmedia Kompitundo.

Gunawan, A. W., (2004), Genius Learning Strategy, Jakarta: Gramedia Pustaka Utama.

Hamid, A. K., 2007, Teori Belajar dan Pembelajaran, Medan: Pasca Sarjana Unimed.

Heinich, R. and Molenda, M. and Russell, D. J., (1985), Instructional Media and The New Teclogies of Instruktion, United State: John Willey \& Son.

Hergenhahn, B. R. and Olson, M., (2008), Theories Of Learning Ed 7, Alih Bahasa Tri Wibowo B. S., Jakarta: Kencana.

Kadir, A. dan Wahyuni, T., (2005), Pengenalan Teknologi Informasi, Yokjakarta: Andi.

Kariman, T. M., (2002), Strategi Pembelajaran Abad 21: Disajikan pada Seminar Nasional Teknologi Pembelajaran, Jakarta: $18 \mathrm{~s} / \mathrm{d} 20$ Juli.

Pahmi, Z. (2005), Pengaruh Pembelajaran dengan Menggunakan Modul dan Kecerdasan Emosional terhadap Keterampilan Merakit Rangkaian Catu
Daya Siswa SMK Teknologi Negeri 4 Medan, Medan: Tesis Unimed.

Parekh, R., (2006), Priciples Of Multimedia, New Delhi: Tata-McGraw Hill

Piaget, J. 1817, Science of Education and The Psychology of Child, New York: Wiley

Romizowski A. J., (1981), Designing Instructional System, (Decision Making in Course Planning and Curriculum Design), London: Kogan Page.

Sadiman, A. dkk., (2003), Media Pendidikan: Pengertian, Pengembangan dan Pemanfaatan, Jakaarta: Raja Grafindo Persada.

Schwier, R. A., \& Misanchuk, R. E., (1994), Instructional atechnology: The Dfinition and Domains of the Field, Washington, DC: AECT.

Slameto, (2003), Belajar dan Faktor-Faktor Yang Mempengsruhinya, Jakarta: Rineka Cipta.

Soemanto, W. 1983, Psikologi Pendidikan Landasan Kerja Pimpinan Pendidikan, Jakarta: Rineka Cipta.

Suparno, A.S., 2004, Membangun Kopetensi Belajar, Jakarta: Direktorat Jenderal Pendidikan Tinggi Depdiknas.

Winkel, W. S., 2007, Psikologi Pengajaran, Jakarta: Grasindo 